\title{
MASIER
}

$$
\text { CONF-810831--57 }
$$

GA-A16389

\section{THE EFFECT OF MICROSTRUCTURE ON THE MECHANICAL PROPERTIES OF A COMMERCIAL 12Cr-1Mo STEEL (HT-9)}

\author{
by \\ T. A. LECHTENBERG
}

AUGUST 1981

\section{GENERAL ATOMIC COMPANY}


GA-A16389

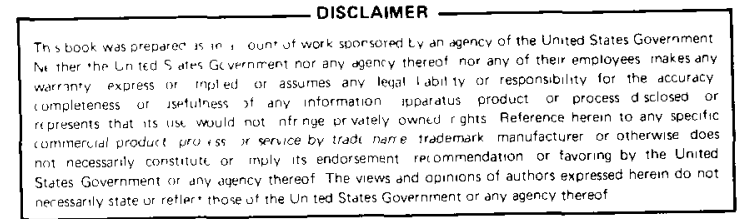

\title{
THE EFFECT OF MICROSTRUCTURE ON THE MECHANICAL PROPERTIES OF A COMMERCIAL 12Cr-1Mo STEEL (HT-9)
}

\author{
by \\ T. A. LECHTENBERG
}

This is a preprint of a paper to be presented at the Second Topical Meeting on Fusion Reactor Materials, August 9-12, 1981, Seattle, Washington, and to be published in the Proceedings.

\author{
Work supported by \\ Department of Energy \\ Contract DE-AT03-76ET51011
}

GENERAL ATOMIC PROJECT 3235.881.001 AUGUST 1981

\section{GENERAL ATOMIC COMPANY}




\section{DISCLAIMER}

This report was prepared as an account of work sponsored by an agency of the United States Government. Neither the United States Government nor any agency Thereof, nor any of their employees, makes any warranty, express or implied, or assumes any legal liability or responsibility for the accuracy, completeness, or usefulness of any information, apparatus, product, or process disclosed, or represents that its use would not infringe privately owned rights. Reference herein to any specific commercial product, process, or service by trade name, trademark, manufacturer, or otherwise does not necessarily constitute or imply its endorsement, recommendation, or favoring by the United States Government or any agency thereof. The views and opinions of authors expressed herein do not necessarily state or reflect those of the United States Government or any agency thereof. 


\section{DISCLAIMER}

Portions of this document may be illegible in electronic image products. Images are produced from the best available original document. 
THE EFFECT OF MICROSTRUCTURE ON THE MECHANICAL PROPERTIES OF

A COMMERCIAL 12Cr-1MO STEEL (HT-9)

Thomas Lechtenberg

General Atomic Company

San Diego, California, U.S.A.

\begin{abstract}
The microstructure of a commercial 12Cr-1Mo steel (HT-9) and its associated effect on strength and toughness properties is being studied in a continuing program aimed at qualifying the alloy for use in fusion energy machines. Interim results show this alloy is subject to a degree of tempered martensite embrittlement and temper embrittlement. For applications projected for fusion machines at lower temperatures, a new heat treatment (1000C, $1 \mathrm{hr}$, air-cooled followed by $650 \mathrm{C}$ tempering) at lower temperatures and shorter times than the vendor-recommended heat treatment has been identified. Microstructural differences between the treatments are discussed. and mechanical properties are correlated.
\end{abstract}

\section{INTRODUCTION}

The class of steels containing $12 \mathrm{Cr}-1$ Mo has been used extensively in fossil-fueled power generation plants in Europe for two decades(1.2). These materials contain enough chromium to give corrosion resistance; however, the total alloy content is 1 imited to insure that the material can be heated to a fully austenitic phase field and subsequently transformed to martensite by air-cooling( 3 ). The condition in which it has been used is sufficiently overtempered (e.g.) $2-1 / 2$ hr at $760 \mathrm{C}$ ) to insure microstructural stability for long service at $600 \mathrm{C}$. The microstructure in this state is still martensitic, in that the lath structure is retained, although the dislocation structure has recovered sufficiently such that it contains ferrite and the laths are surrounded by carbides( 1 ). The presence of secondary carbide forming elements such as chromium, tungaten, molybdenum, and vanadium causes alloy carbides to precipitate and, combined with a very fine lath structure, gives this material superior creep resistance $(5,6)$. The U.S. fusion effort is interested in a $12 \mathrm{Cr}-$ 1 Mo-0.3V-0.5W steel (HT-9) because it has shown wuch less swelling due to irradiation than austenitic steels( 7$)$. The neutronic enviroment in fusion machines will be significantly more energetic than that for fast reactors from which these data were generated. It is therefore expected that results for $12 \mathrm{Cr}-1 \mathrm{MO}_{0}$ at higher fluence levels will demonstrate its superiority more dramatically. The next generation fusion machine, called the Fusion Engineering Device (FED), has low lifetime fluences and thus will not utilize $12 \mathrm{Cr}-1$ Mo alloy except for material test panels. However, this alloy has been designated as the reference material for the first wall/blankets in several future fusion machines $(8,9)$. Due to the critical tempersture control required for martensitic steels in fabrication and welding, the Alloy Development for Irradiation Performance (ADIP) task group from the Office of Fusion Energy has been studying these and other aspects to determine the feasibility of 12Cr-1Mo for use in the sort of struc- tures envisioned for tokamaks. An understanding of the basic metallurgy of this specific alloy is critical in determining the microstructural relationships to the observed mechanical properties in the fabricated, heat-treated, and welded conditions and relating them to postirradiation properties and microstructures. It is also noted that the vendor heat treatment has been developed for applications at $600 \mathrm{C}$. In most designs, fusion first walls are at lower temperatures, and it is suggested that heat treatment variations may yield a fundamentally superior microstructure for resistance to irradiation damage and thermal embrittlement.

This paper presents interim results of a continuing program to determine the effect of thermal aging of $12 \mathrm{Cr}-1 \mathrm{Mo}-0.3 \mathrm{~V}-0.5 \mathrm{~W}$ steel (HT-9) on several microstructures produced by different heat treatments, and comparisons of the results with those using the vendor-recommended heat treatment.

\section{EXPER IMENTAL}

The chemistry of the steel is Fe-0.21C$1.01 \mathrm{MO}-0.54 \mathrm{~W}-0.33 \mathrm{~V}-0.58 \mathrm{Ni}-0.50 \mathrm{Mn}-0.21 \mathrm{Si}-0.008 \mathrm{P}-$ $0.003 \mathrm{Si}$. The reader is referred to Ref. 10 for all the necessary experimental details.

\section{RESULTS AND DISCUSSION}

Figure 1 shows the effect of austenization temperature on the hardness and prior austenitic grain size of the $12 \mathrm{Cr}-1$ ko steel held for one hr at temperature and air-cooled. Grain sizes were determined by comparison at $100 \mathrm{X}$ to a standard template. If the material during austenitization is fully in the fcc-austenite phase field. the as-quenched hardness is a function of the carbon content of the steel(11,12). Therefore. the hardness is a relative measure of the carbide dissolution at different temperatures. This can be seen in Fig. 1. From 950 to $1100 \mathrm{C}$, the hardness increases from $R_{C} 41$ and remains nearly constant above $1000 \mathrm{C}$ at $R_{c}$ 46-47. Fran 900 to $950 \mathrm{C}$ the hardness increases signifi- 


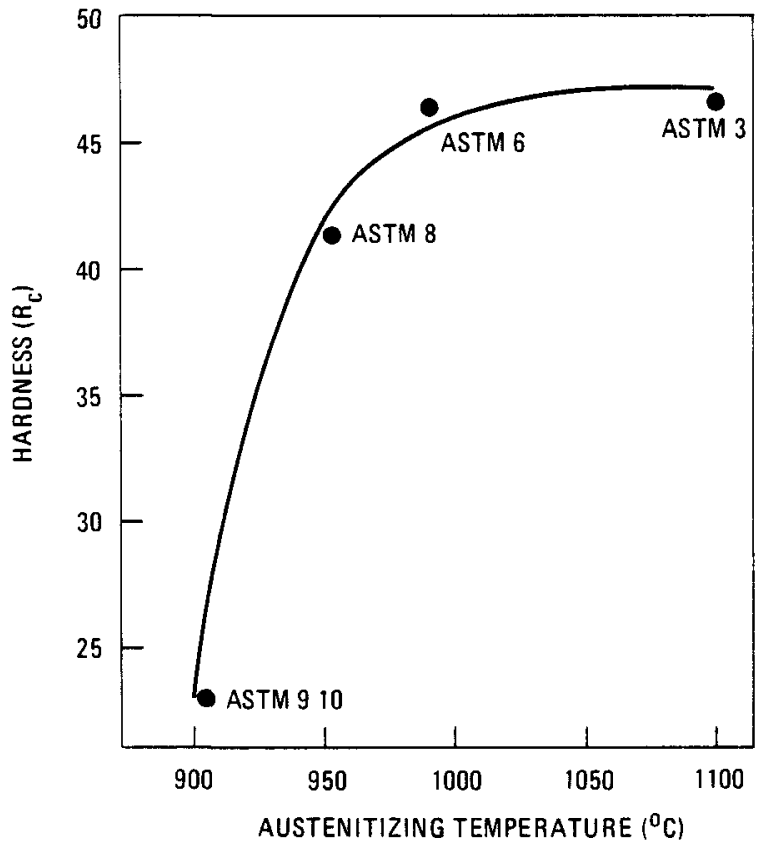

Figure 1 The effect of austenitization temperature on the hardness and grain size of $12 \mathrm{Cr}-1 \mathrm{Mo}$ (HT-9) steel heated for an hour and air cooled.

cantly. Optical metallography showed that this was related to the presence of ferrite at the lower temperature. The carbides which remalned undissolved from 950 to $1100 \mathrm{C}$ were extracted and determined to be $\mathrm{M}_{23} \mathrm{C}_{6}$ with a lattice parameter of $1.064 \mathrm{~nm}$. The amount extracted decreased as the austenitization temperature increased. The effect of tempering temperature on hardness as a function of austenitizing temperature is shown 1n Figure 2. There are several features to note. First, this material displays the characteristic secondary hardening profile. The strong carbide-forming elements $\mathrm{Cr}$, Mo, $W_{3}$ and $V$ w11l precipitate as secondary carbides (that $1 \mathrm{~s}$, after the primary $M_{3} C$ has overaged and $d_{1} s^{-}$ solved) on dislocations which serves to pin them. It is this pinning action which increases the yield stress. Secondly, the peak hardness occurs around $500 \mathrm{C}$ and the peak helght is greatest at higher austenitizing temperatures. This is an important indication of how prior microstructure (e.g.. undissolved carbides) can influence mechanical properties. More carbon and secondary hardening elements are avallable for precipitation due to dissolving $\mathrm{M}_{23} \mathrm{C}_{6}$. Austenitizing at 1000 and $1050 \mathrm{C}$ yields the same secondary hardening peak hardness, indicating the $\mathrm{M}_{23} \mathrm{C}_{6}$ carbide was relatively stable over that range for $1 \mathrm{hr}$. However, austenitizing at $1100 \mathrm{C}$ ylelds a higher secondary peak, $R_{c} 51$, up from $R_{c} 47$. This 25 probably due to the strong $1 \mathrm{n}-$ fluence of small increases in carbon content of the matrix as $\mathrm{M}_{23} \mathrm{C}_{6}$ dissolves(13). Finally, the overaging characteristics appear different for higher austenitization temperature. F1g. 2 shows that strength decreases more rapidly as a function of tempering temperature when the austenitization is at higher temperatures.

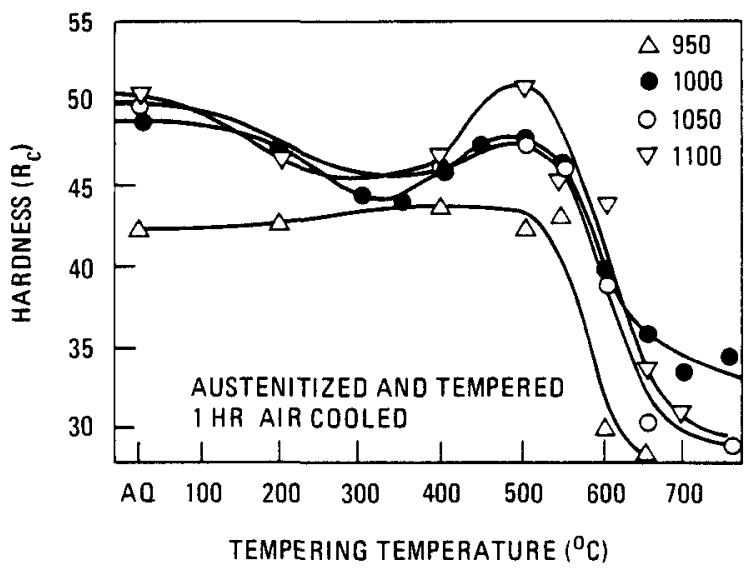

Figure 2 The effect of tempering temperature on hardness as a function of austenitization temperature.

The effect of tempering on the room temperature Charpy impact toughness is shown in Fig. 3 . Dynamic yield stress is reported along with the hardness (which is a function of the ultimate tensile stress), and these are compared to impact toughness. The toughness values increase from the as-quenched to $200 \mathrm{C}$ tempered condition. At 250 to $350 \mathrm{C}$ it levels off at $20 \mathrm{~J}$ even though hardness was decreasing through this range, but increases to $30 \mathrm{~J}$ at $400 \mathrm{C}$. This 18 probably due to tempered martensite embrittlement (also called '350C' or '500F' or 'one-step temper'(14) embrittlement). The large decrease in toughness from 450 and to $550 \mathrm{C}$ is in the temper embrittlement regime for this material(15) and is probably due to tramp impurity elements such as 5 and $P$ causing a 'micropollution'(16) of boundaries, rendering them weaker. More work is being done to determine the exact cause. At higher temperatures the material loses strength sufficiently to allow much more ylelding prior to fallure. which is manifested by an increase in toughness.

\section{CORRELATION OF MICROSTRUCTURE AND MECHANICAL PROPERTIES}

This section discusses continuing microstructural observations. Figure 4 shows a transmission electron m2crograph of the $1000 \mathrm{C}$ as-quenched condition. It is typical of interlocking lath martensite structures. An arrow points to an undissolved $\mathrm{M}_{23} \mathrm{C}_{6}$ carbide. Dark field diffraction analysis in part (b) showed that some austenite was retained at the martensite latgh boundaries as thin films, approximately $200 \mathrm{~A}$ 


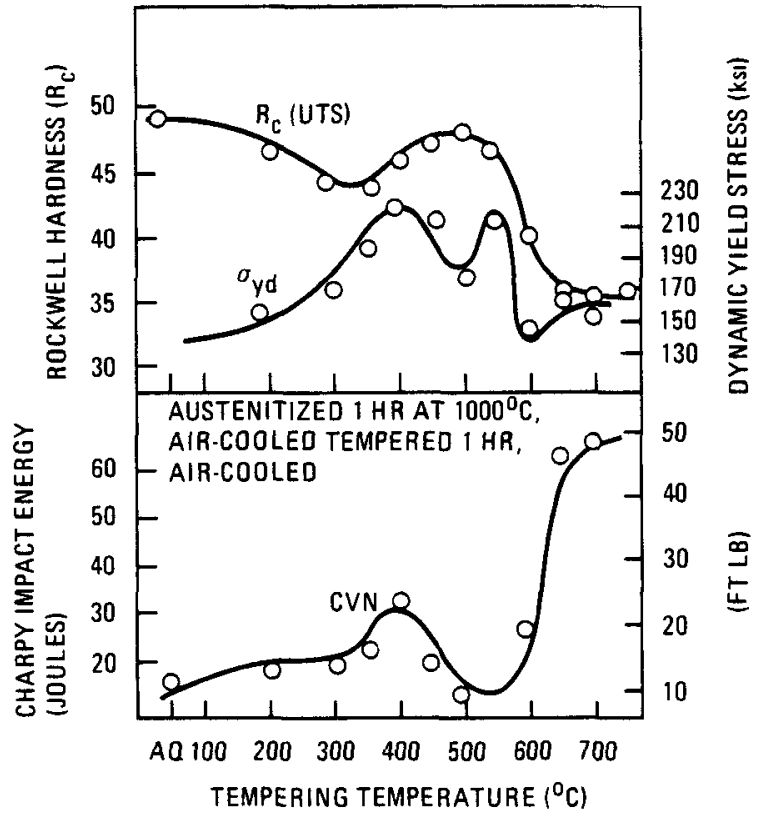

Figure 3 The effect of tempering temperature on hardness, dynamic yield stress, and Charpy impact toughness after austenitizating $I$ hr at $1000 \mathrm{C}$ and tempering for $1 \mathrm{hr}$, both followed by air-cooling.

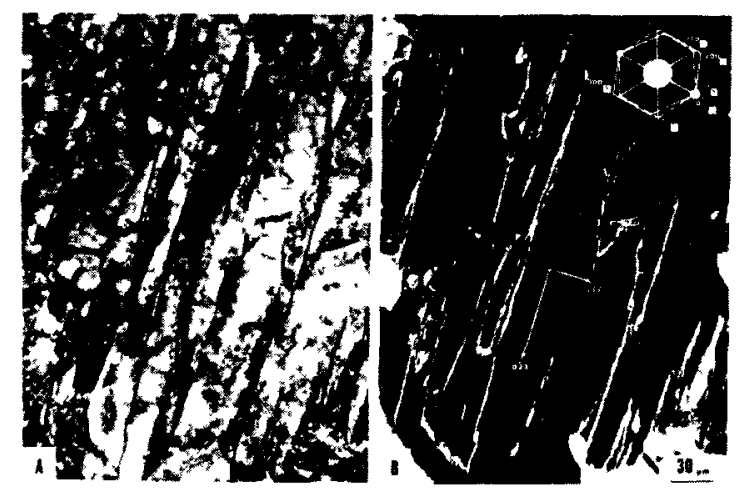

Figure 4 Transmission electron micrograph of 1000C, I hr, air-cooled microstructure showing (a) interlocking dislocated lath martensite, and (b) a dark field showing thin films of retained austenite surrounding the laths.

thick. This has been reported previously and is the cause of subsequent tempered martensite embrittlement when the austenite decomposes(17). The austenitized and air-cooled from $1050 \mathrm{C}$ condition was also observed. There was an increase in the amount of retained austenite at the lath boundaries. This also has been reported for a silicon-modified 4340 steel(18) and a 300-M steel(19). Tempering will subsequently cause the retained austenite films to decompose. ob- servations show this is complete by $350 \mathrm{C}$. In Fig. 3 there was a pause in the expected increase in toughness values between 250 and $350 \mathrm{C}$. These carbides are of the $\mathrm{M}_{3} \mathrm{C}$ type. At $500 \mathrm{C}$ carbides have precipitated within the martensite laths causing the secondary hardening peak. These have the morphology of $\mathrm{M}_{2} \mathrm{C}$ but as yet are not identified. Results from similar studies have reported $\mathrm{Mo}_{2} \mathrm{C}$ as the strengthening carbide (20), although that is known to compete with MC carbides in some cases(21). The structure after austenitizing at $1000 \mathrm{C}$ and tempering at $650 \mathrm{C}$ is shown in Fig. 5. The martensite laths are surrounded by $\mathrm{M}_{23} \mathrm{C}_{6}$ carbides forming a semicontinuous network. In this condition the impact energy has increased significantly to $\sim 70 \mathrm{~J}$, indicative of a loss in strength. The microstructure shows that all precipitation is now in the lath boundary. Because carbides no longer pin dislocations, the dynamic yield stress decreases in this condition, as seen in Fig. 3.
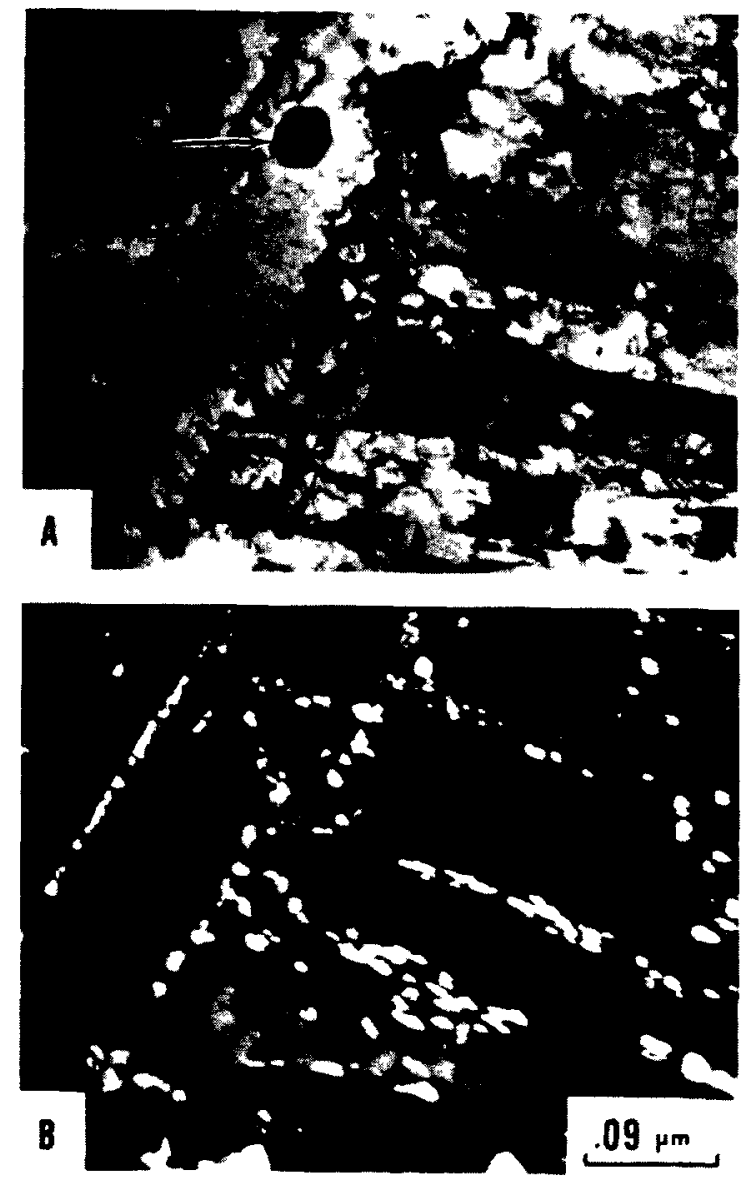

Figure 5 Transmission electron micrograph of quenched and tempered condition (1000C. $650 \mathrm{C}$, both $1 \mathrm{hr}$, air-cooled) showing that the retained austenite films decompose to $\mathrm{M}_{23} \mathrm{C}_{6}$ carbides. This has been called tempered martensite embrittlement. 
The 12Cr-1Mo steels exhibit microstructural stability. Recently it was shown that the martensite lath structure remains intact even after 80,000 hr at $600 \mathrm{C}(2)$, although there is significant subgrain formation. The microstructure of the $12 \mathrm{Cr}$ steel after austenitizing and tempering at 1000 and $650 \mathrm{C}$ for $1 \mathrm{hr}$ and air-cooling, and subsequently aged at $550 \mathrm{C}$ for $100 \mathrm{hr}$ was similar to that shown in Fig. 5. There was little more precipitation of $\mathrm{M}_{23} \mathrm{C}_{6}$ carbide due to thermal aging, indicating the quenched and tempered condition to be close to equilibrium. This was also true for the lath and carbide morphology. Precracked and instrumented Charpy impact test results are shown in Fig. 6. It can be seen that the ductile-brittle transition temperature (DBTT) has increased 60c. The fracture mode from the upper-shelf knee and lower temperatures was interlath cleavage with some ductile tearing between laths in all cases. Concurrent with this, standard Charpy tests were performed. The results did not indicate an increase in the DBTT, that is the blunt notch test was insensitive to this degree of embrittlement.

\section{SUMMARY}

From the data presented several conclusions can be drawn which relate the microstructural relationships to mechanical properties. It has been established that the $12 \mathrm{Cr}-1 \mathrm{Mo}$ steel (HT-9) is subject to tempered martensite embrittlement, which is a 1088 in toughness when the material is tempered near 350C. This is due to retained austenite films around martensite laths decomposing to $\mathrm{M}_{3} \mathrm{C}$. Furthermore, even at higher tempering temperatures, the films decompose and leave semicontinuous networks of $\mathrm{M}_{23} \mathrm{C}_{6}$ carbides at the lath boundaries. These may act as crack nucleators, and the fracture surfaces appear to have cleaved at the martensite lath boundaries. Also, temper embrittlement was observed in that there was a shift in DBTT when the material was

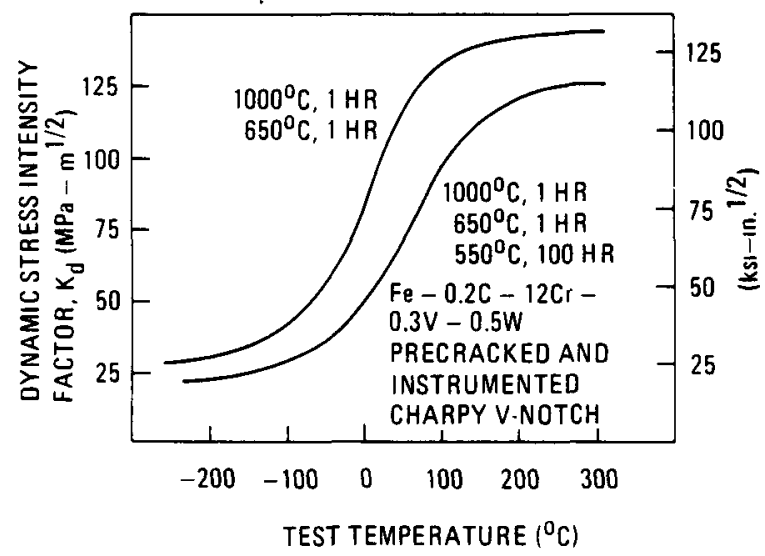

Figure 6 The effect of test temperature on the precracked Charpy impact toughness, $K_{d}$. after aging for $100 \mathrm{hr}$ at $550 \mathrm{C}$. All fracture modes were interlath cleavage with some ductile tearing between them. aged at $550 \mathrm{C}$ for $100 \mathrm{hr}$ while there was no discernible change in microstructure.

The fracture data suggest that blunt notched tests are less sensitive messurements of embrittlement. A realistic flaw in a structure would be very sharp. such as a fatigue crack; therefore, it is suggested that a true picture of the degree of embrittlement is obtained from measurement of fatigue cracked specimens. Also the small size of many irradiation specimens if precracked will yield more constraint and therefore a truer measure of embrittlement.

\section{ACKNOWLEDGEMENTS}

I am grateful for the continuing support of the U.S. Department of Energy under contract DE-AT03-76ET51011.

\section{REFERENCES}

[1] Persson, N., Characteristics of Hardenable $12 \mathrm{Cr}$ Steels for Energy Conversion Systems, Alloys for the Eighties, Barr, R. (ed.), Climax Molybdenum Company, Greenwich. Conn., (1980), 143.

[2] Chafey, J, and Thompson, L., Post-Service Evaluation of the Properties of a $12 \mathrm{Cr}-1 \mathrm{Mo}$ Steel Superheater Tube, in Proceedings, Materials-Environment Interactions in Structural and Pressure Containment Service Symposium (ASME, New York. NY 1980) 53.

[3] Metals Handbook, 8th Ed., Vol. 8, (ASM, Metals Park, Ohio 1973) 291.

[4] Isothermal Transformation Diagrams, U.S. Steel, 3rd Ed.. (U.S. Steel 1963) 49.

[5] Little, E., Harries, D., Pickering, F., and Keown, S., Effects of Heat Treatment on Structural Properties of 12Cr Steels, Metals Tech (April 1977) 205.

[6] Rout sky, J. and Jezek, J.. High-Temperature Properties of $12 \mathrm{Cr}$ steels Alloyed with Tungsten, Molybdenum and Vanadium. J. Iron and Steel Institute, 203 (1965) 707.

[7] Rosenwasser, S., Miller, P.. Dellassandro, J., Rawls, J., Toffalo, W.., and Chen, W., Applications for Martensitic Stainless Steels in Fusion First Wall/Blanket Structures, J. Nuclear Materials, 85 and 86 (1979) 177

[8] Kulcinski, G.. et al, presented at 4 th Topical Meeting on Technology of Controlled Nuclear Fusion, October 14, 1980, King of Prussia, PA.

[9] Cheng, E., et al, to be presented at 9 th Symposium on Engineering Problems of Fusion Research, Chicago, Illinois, October 26, 1981 .

[10] Lechtenberg, T.. Microstructural Evaluation of Embrittled $12 \mathrm{Cr}-1 \mathrm{Mo}-0.3 \mathrm{~V}$ Steel, ADIP Quarterly Progress Report for period ending December 31, 1980, DOE/ER-0045/5, 43.

[11] Read-Hill, R.. Physical Metallurgy Principals, 2nd Ed., (D. van Nostrand, New York, NY 1973) 726 .

[12] Bain, E., and Paxton, H., Alloying Elements in Steel. (ASM, Metals Park, OH 1966) 37. 
[13] Roberts, G., Hamaker, J., and Johnson, A., Tool Steels, 3rd Ed.. (ASM, Metals Park, OH 1971).

[14] Horn, R., and Ritchie, R.. Mechanism of Tempered Martensite Embrittlement in Low Alloy Steels, Met Trans A, 9A(8) (1978) 1039.

[15] Edwards, B., and Little, E.. Tempered Martensite Embrittlement in a $12 \mathrm{Cr}$ steel. Ferritic Steels for Fast Reactor Steam Generators, (BNES, London 1978) 145.

[16] Ritchie, R.. Influence of Impurity Segregation on Temper Embrittlement on Slow Fatigue Crack Growth and Threshold Behavior in 300-M High Strength Steel, Met Trans A, 8 A (1977) 1131 .

[17] Thomas, G.. Retained Austenite and Tempered Martensite Embrittlement. Met Trans A, 9A (1978) 439

[18] Bhat, M., Microstructural Mechanical Properties of 4340 Steel Modified with Silicon and Aluminum, Ph.D. Thesis, University of California, Lawrence Berkeley Laboratory Report 6046. February 1977.

[19] Lechtenberg. T. A Comparison of the Microstructure and Mechanical Properties of 300-M Steel Manufactured by the VAR and ESR Techniques, M.S. Thesis, University of California, Lawrence Berkeley Laboratory Report $6686,1977$.

[20] Honeycomb, R.. Structural Strength of Alloy Steels, (Climax Molybdenum Company, 1972).

[21] Lechtenberg, T.. The Microstructure, Mechanical Properties, and Two-body Wear Resistance of a Modified $\mathrm{W}-\mathrm{Cr}-\mathrm{Mo}-\mathrm{W}$ Tool steel. Ph.D. Thesis, U.C. Press, University of California, Berkeley, California, 1979. 